\title{
The Banana Tree at the Gate: A History of Marginal Peoples and Global Markets in Borneo
}

Michael R. Dove. New Haven, CT: Yale University Press, 2011. Xix, 332 pp. Illus. Bibliography, indexes. ISBN

978-0-300-15321-7 (hardcover). \$55.00

Reviewed by E. N. Anderson ${ }^{1}$

Reviewer Address: ${ }^{1}$ Department of Anthropology, University of California, Riverside.

Received: October 12, 2011

Volume 3:13

Published: March 7, 2012

(C) 2012 Society of Ethnobiology

Michael Dove has been a leader in the field of political ecology since it began. With this book, which recently won the Julian Steward Prize for the best ecological anthropology book of 2011, he consolidates his standing in the field. This is a major work that should be read by anyone interested in the fate of traditional societies and their economies in the modern world.

The book builds on Dove's decades of research among the Kantu' Dayak of the remote interior of Kalimantan (Indonesian Borneo). The title comes from a local proverb; a banana tree at a front gate is unprotected and becomes fair game for anyone who wants to snitch some fruit. The "marginal peoples" of Borneo and elsewhere are indeed vulnerable to exploiters. In this case, pepper is the commodity of choice. The Kantu', like many in Indonesia, have grown it for centuries as a cash crop. The vicissitudes of the trade over the last couple of centuries emerge from Dove's account. The usual story appears: the actual growers are at the mercy of a long chain of authorities, from local political figures to Dutch colonials and then to the world market. Dove also considers the role of rubber as a smallholder crop, showing the success of smallholders at producing it. They are fully competitive with modern plantations. I have observed the same phenomenon in Malaysia.

Yet, unlike too many such books, this work is not a victims-and-villains melodrama. The Kantu' maintain themselves as subsistence cultivators, they continue to survive and keep their culture going, and they take every opportunity to get something back from the system. When pepper does not sell, they fall back on food crops; when pepper provides opportunity, they seize that. They keep trying for political agency through it all. Dove reads and interprets the Hikayat Banjar, a local historical text (a hikayat is history fictionalized enough to make a good story, but still basically founded on fact). He finds much commentary therein on the world-system and Borneo's marginal place in it.

One is led to respect the indigenous smallholders rather than simply blame the unfair world - though the latter is certainly not spared. Dove is well aware of issues of representation, and deals forthrightly with the problems of how to represent indigenous and less than affluent cultivators. Earlier generations had their stereotypes, including the inevitable colonial ones; how will we do better?

Intellectual issues also include most of the serious topics of current political ecology, from smallholder rights to "globalization." Dove points out that Indonesia has been well integrated into world trade networks for millennia. Pepper, as well as cloves and other spices, were traded to China from early times. The Indian Ocean and South China Sea were almost, or quite, as busy as the Mediterranean, from the Roman Empire onward; Roman coins abound in south India. The speed and volume of transport has increased, but dynamics of peripheralization and exploitation are not much changed. I am reminded of my own favorite Malaysian proverb: "Even though ten ships come, the dogs have no loincloths but their tails." The ships are understood to be carrying luxury imported fabrics, the choicest goods in the old Malaysian trade. Low-status humans, like canines, have slim chances of getting any.

Being the product of decades of work and reflection by one of the most thoughtful, insightful, and industrious anthropologists of our time, this book defies summary. I can only urge all those interested in human ecology to obtain a copy. 